\title{
Attitudes towards 'superfood' depending on the risk of orthorexia among students in Poland and The Netherlands
}

\section{Postawy wobec żywności „superfood” w zależności od ryzyka ortoreksji wśród studentów z Polski i Niderlandów}

\author{
Karolina Osowiecka ${ }^{1, A-D, F} \oplus$, Joanna Myszkowska-Ryciak ${ }^{1, A, C, E-F \oplus}$ \\ ${ }^{1}$ Department of Dietetics, Institute of Human Nutrition Sciences, Warsaw University of Life Sciences (WULS), Warsaw, Poland \\ A - Research concept and design, B - Collection and/or assembly of data, C - Data analysis and interpretation, \\ $D$ - Writing the article, E - Critical revision of the article, F - Final approval of article \\ Osowiecka K, Myszkowska-Ryciak J. Attitudes towards 'superfood' depending on the risk of orthorexia among students in Poland and The \\ Netherlands. Med Og Nauk Zdr. 2020; 26(4): 378-383, doi: 10.26444/monz/125389
}

\section{Abstract}

Introduction. Orthorexia nervosa is an eating disorder that can affect young people. It is characterized by excessive care for the quality of consumed products, also in terms of their positive effect on the human body. This type of food, both with high nutritional quality and health-promoting properties, includes products called 'superfood' (e.g. goji berries, chia seeds).

Objective. The aim of the study was to assess the risk of orthorexia and to analyze attitudes towards 'superfood' among students from the Warsaw University of Life Sciences (WULS), Poland, and Wageningen University \& Research (WUR) in Wageningen, The Netherlands.

Materials and method. 240 students participated in the study. The risk of orthorexia was assessed on the basis of a validated ORTO-15 questionnaire, with a cut-off point of 35 points. Knowledge and attitudes towards 'superfoods' were evaluated based on the author's questionnaire, including also questions about anthropometric and socio-demographic characteristics. Results. The examined groups of students were of a similar age (WULS $22.0 \pm 3.0$ years; WUR $22.8 \pm 4.6$ years), $75 \%$ of the respondents had normal body weight. About $30 \%$ of students from WULS and $26 \%$ from WUR showed the risk of orthorexia. The best-known products with health-promoting properties were: ginger, ginseng, chia seeds and aloe vera. In contrast, the most frequently consumed were ginger and turmeric. A relationship between orthorexia and superfood consumption was observed for goji berries, amaranth (WULS students) and ginseng (WUR students).

Conclusions. The relationship between orthorexia and the knowledge and consumption of superfoods products was shown only for 3 products. The obtained results could have been influenced by the small percentage of students with a confirmed risk of orthorexia in the study group. Therefore, to formulate binding conclusions about the relationship between orthoretic behaviour and the knowledge and consumption of superfoods products, further research on a bigger study group is recommended.

\section{Key words}

orthorexia nervosa, superfood, eating behavior, nutritional knowledge, young adults, eating disorders

Address for correspondence: Karolina Osowiecka, Department of Dietetics, Institute of Human Nutrition Sciences, Warsaw University of Life Science (WULS), Warsaw, Poland E-mail: osowiecka.karolina@wp.pl

Received: 17.04.2020; accepted: 14.07.2020; first published: 04.08.2020

\section{Streszczenie}

Wprowadzenie. Ortoreksja nervosa jest zaburzeniem odżywiania, które może dotyczyć osób młodych. Cechuje się nadmierną dbałością o jakość spożywanych produktów, również w aspekcie ich pozytywnego wpływu na organizm człowieka. Do tego typu żywności, cechującej się zarówno wysoką jakością odżywczą, jak właściwościami prozdrowotnymi, należą produkty określane pojęciem „superfood” (m.in. jagody goji, nasiona chia).

Cel pracy. Celem pracy była ocena ryzyka wystąpienia ortoreksji oraz analiza postaw wobec żywności typu superfood wśród studentów Szkoły Głównej Gospodarstwa Wiejskiego (SGGW) w Warszawie oraz Wageningen University \& Research (WUR), Holandia.

Materiał i metody. W badaniu wzięło udział 240 studentów. Ryzyko ortoreksji oceniano na podstawie walidowanego kwestionariusza ORTO-15, z punktem odcięcia na poziomie 35 pkt. Wiedzę i postawy względem produktów typu superfood oceniano na podstawie autorskiej ankiety, obejmującej również pytania o wyróżniki antropometryczne i socjodemograficzne. Wyniki. Badane grupy studentów były w podobnym wieku (SGGW 22,0 \pm 3 ,0 lata; WUR 22,8 \pm 4,6 roku), 3/4 ankietowanych miało prawidłową masę ciała. Ryzyko ortoreksji wykazywało ok. 30\% studentów SGGW oraz 26\% WUR. Najczęściej rozpoznawalnymi produktami o właściwościach prozdrowotnych były: imbir, żeń-szeń, nasiona chia oraz aloes. Natomiast najczęściej spożywane były imbir oraz kurkuma. Zależność między ortoreksją a spożyciem produktów typu superfood zaobserwowano w przypadku jagód goji, amarantusa (tylko w grupie studentów SGGW) oraz żeń-szenia (tylko wśród studentów WUR).

Wnioski. Zależności pomiędzy ortoreksją a znajomością i spożywaniem produktów typu superfood wykazano tylko dla 3 produktów. Na uzyskane wyniki mógł mieć wpływ niewielki odsetek studentów ze stwierdzonym ryzykiem ortoreksji w badanej grupie. Dlatego dla sformułowania wiążących wniosków dotyczących zależności pomiędzy zachowaniami ortorektycznymi a wiedzą i spożywaniem produktów typu superfood zaleca się dalsze badania przeprwadzone na większej liczbie osób.

\section{Słowa kluczowe}

ortoreksja nervosa, superfood, zachowania żywieniowe, wiedza żywieniowa, młodzi dorośli, zaburzenia odżywiania 


\section{INTRODUCTION}

Orthorexia nervosa is defined as a pathological focus on eating healthy food. It is an eating disorder that might be hazardous to the health and life of the individual concerned, because it can lead to malnutrition, metabolic acidosis, severe nutrients deficiencies or other health disorders in the human body [1]. To assess the risk of orthorexia in an individual, the ORTO-15 questionnaire based on the BOT (Bratman Orthorexia Test) is typically used [2]. This disorder can affect people with features such as perfectionism, obsessive compulsive diet, or other eating disorders in the patient's history. On the other hand, the relationships between orthorexia and body mass index (BMI), commitment to exercise, alcohol consumption or smoking were not always observed [3]. A vulnerable group, due to frequent attitudes and shaped personality, and positive results of screening tests for eating disorders, are young people, including students $[4,5]$. The aim of an orthorectic patient is to achieve a perfectly healthy and high-nutritional diet to maintain health. Therefore, the disorder manifests itself through extensive control regarding the choice of the quality of consumed products, the way they are prepared, as well as the avoidance of preservatives and other food additives. The characteristic symptoms are guilt or obtrusive thoughts, due to less dedication to eating activities [1]. Good nutritional quality products are considered to include socalled 'superfoods', products from exotic countries as well as those occurring in Poland. These are products of plant origin, used as a panacea for disease ailments or as a basic component of nutrition. They are characterized by high nutritional density with a low product weight, e.g. are a rich source of polyunsaturated fatty acids and minerals, as well as other biologically active compounds important in the diet (polyphenols, flavonoids etc.). Examples of such products can be the seeds of chia, acai berries and goji $[6,7]$.

\section{OBJECTIVE}

It was hypothesized that knowledge about superfoods and the consumption of this type of food products might be higher among individuals at the risk of orthoretic behaviour. Therefore, the aim of the study was to assess the risk of orthorexia, and to analyze attitudes and nutritional behaviors towards 'superfoods' depending on orthorexia risk among students in Poland and The Netherlands.

\section{MATERIALS AND METHOD}

The survey was conducted between May - August 2017 using the CAWI (Computer-Assisted Web Interviewing) method. A questionnaire was distributed via the Internet, allowing full anonymity of the respondents. Volunteers were recruited through discussion forums on Facebook, conducted by two universities: WULS (Warsaw University of Life Sciences) in Poland and WUR (Wageningen University \& Research) in The Netherlands. Both institutions are large universities with life-sciences faculties. The inclusion criteria for the study were: consent to complete the survey, being a regular student at the university when filling out the survey, and answering all questions. Respondents temporarily studying at the university (e.g. as part of the Erasmus student exchange), students who completed courses (before defending their thesis) and individuals who incorrectly completed the questionnaire or did not answer all questions, were excluded. It was assumed that with the estimated number of students (WULS $=27,000$ and $W U R=12,000)$, recruiting at least 100 respondents from each university will allow achieving statistically significant results (maximum error up to $10 \%$ with a $95 \%$ confidence level). The sampling method was random sample selection. Finally, during the four months of recruitment, 274 students from both universities filled in the questionnaire, of which 240 individuals were included in the statistical analysis (Fig. 1).

Respondents were asked to answer questions from the validated ORTO-15 questionnaire (Polish version) [8]. A cutoff point of 35 for both populations was adopted, because to the best of the authors' knowledge there is no validation for the ORTO-15 questionnaire for the Dutch population. Another part of the questionnaire contained questions about socio-demographic features, such as gender, age, weight and height, place of residence, level and profile of education, use of supplements, self-assessment of e physical activity level, and economic situation. The respondents also answered questions about their health compared to peers, smoking tobacco, alcohol consumption and diet.

In the last part of the questionnaire, examples of 'superfood' products were listed to assess respondents' knowledge, declared level of knowledge, sources of obtaining information, and typical consumption of these products. As 'superfood' is a marketing term not commonly used by experts, dietitians and nutrition scientists, it is difficult to find scientific literature on the subject. Therefore, the questionnaire was created on the basis of the most popular 'superfood' products appearing in media and popular science articles, and at the same time characterized by pro-health activity confirmed in scientific publications. Most of the questions required one answer. Multiple answers were possible for questions about the use of diets, known and consumed 'superfood' products, and sources of nutritional knowledge about them (maximum 3 answers). Answers on a Likert type scale were typically 5 grades. They concerned questions about: assessment of individual economic situation (very bad / bad / moderate / good / very good); assessment of diet (very bad / bad / moderate / good / very good); assessment of health compared to peers (big worse / worse / comparable / better / much better); and assessment of nutritional knowledge about 'superfood' products (very low / low / moderate / high / very high). Assessment of the change in health after including 'superfood' products in their diet scored 6 points on the Likert scale (much worse / worse / without any change / better / much better / I do not consume this type of products), and the validated ORTO-15 questionnaire consisting of a 4-point scale: never / sometimes / often / always. Respondents were also asked about the change in their health status after including these products in their diet, and typical shopping places. BMI $\left(\mathrm{kg} / \mathrm{m}^{2}\right)$ was calculated on the basis of anthropometric parameters to assess nutritional status. The World Health Organization (WHO) criteria were used: $\mathrm{BMI}<18.5 \mathrm{~kg} / \mathrm{m}^{2}=$ underweight; $18.5-24.9 \mathrm{~kg} / \mathrm{m}^{2}=$ normal weight; $25.0-29.9 \mathrm{~kg} / \mathrm{m}^{2}=$ preobesity; $\geq 30 \mathrm{~kg} / \mathrm{m}^{2}$ obesity (class I, II, III) [9].

Software Statistica 13.1 was used to interpret the obtained results. Chi-square (Pearson) test was used to assess the relationships between categorical variables. Differences were considered statistically significant at $\mathrm{p}<0.05$. 


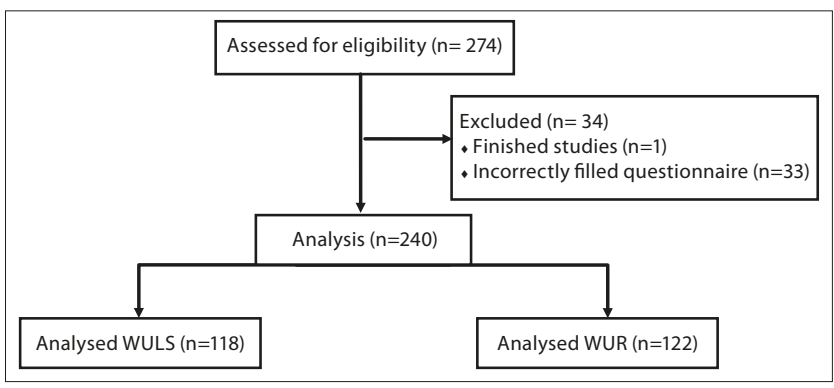

Figure 1. Flow diagram of the study

\section{RESULTS}

The characteristics of the study group are shown in Table I. Most of the respondents were women. There were no differences in terms of gender distribution between universities. There was no relationships between orthorexia

Table 1. Characteristics of students from Poland and The Netherlands $(n=240)$

\begin{tabular}{|c|c|c|}
\hline Characteristics of the group & $\begin{array}{l}\text { WULS students } \\
\qquad(\mathrm{n}=118)(\%)\end{array}$ & $\begin{array}{l}\text { WUR students } \\
(n=122)(\%)\end{array}$ \\
\hline \multicolumn{3}{|l|}{ Gender } \\
\hline Female & $103(87.3)$ & $101(82.8)$ \\
\hline Male & $15(12.7)$ & $21(17.2)$ \\
\hline \multicolumn{3}{|l|}{ Age (years) } \\
\hline$\leq 20$ & $43(36.4)$ & $39(32)$ \\
\hline $21-25$ & $68(57.6)$ & $62(50.8)$ \\
\hline $26 \leq$ & $7(6)$ & $21(17.2)$ \\
\hline \multicolumn{3}{|l|}{ BMI $\left(\mathbf{k g} / \mathbf{m}^{2}\right)$} \\
\hline Underweight & $17(14.4)$ & $14(11.4)$ \\
\hline Normal weight & $83(70.3)$ & $90(73.8)$ \\
\hline Overweight & $13(11)$ & $13(10.7)$ \\
\hline Obesity & $5(4.3)$ & $5(4.1)$ \\
\hline \multicolumn{3}{|l|}{ Place of residence } \\
\hline Village & $25(21.2)$ & $16(13.1)$ \\
\hline City up 10,000 inhabitants & $9(7.6)$ & $16(13.1)$ \\
\hline City between $10,000-50,000$ inhabitants & $16(13.6)$ & $78(63.9)$ \\
\hline City between $50,000-100,000$ inhabitants & $5(4.2)$ & $4(3.3)$ \\
\hline City between $100,000-500,000$ inhabitants & $8(6.8)$ & $1(0.8)$ \\
\hline City with more than 500,000 inhabitants & $55(46.6)$ & $7(5.8)$ \\
\hline \multicolumn{3}{|l|}{ Economic situation } \\
\hline Bad or very bad & $8(6.8)$ & $13(10.7)$ \\
\hline Moderate & $56(47.5)$ & $71(58.2)$ \\
\hline Good & $46(38.9)$ & $32(26.2)$ \\
\hline Very good & $8(6.8)$ & $6(4.9)$ \\
\hline \multicolumn{3}{|l|}{ Current level of education } \\
\hline Bachelor & $95(80.5)$ & $60(49.2)$ \\
\hline Master & $21(17.8)$ & $53(43.4)$ \\
\hline PhD or post-graduate education & $2(1.7)$ & $9(7.4)$ \\
\hline \multicolumn{3}{|l|}{ Level of physical activity } \\
\hline Sedentary & $34(28.8)$ & $14(11.5)$ \\
\hline Moderate & $58(49.2)$ & $60(49.2)$ \\
\hline High & $26(22)$ & $48(39.3)$ \\
\hline
\end{tabular}

and gender in the case of WULS ( $p>0.05)$, whereas in the case of WUR, a tendency to significance was shown among the respondents $(\mathrm{p}=0.056)$. Among the WULS students, the youngest respondent was 19-years-old, while the oldest was 40-years-old (average 22.0 \pm 3.0 years), and among the WUR students the age range was $17-53$ years (average $22.8 \pm 4.6$ years). There was no relationship between age and orthorexia nervosa at both universities. Almost $3 / 4$ people had normal body weight, and only 31 were underweight (average BMI WULS $22.0 \pm 3.4 \mathrm{~kg} / \mathrm{m}^{2}$; WUR $21.6 \pm 3.5 \mathrm{~kg} / \mathrm{m}^{2}$ ) (Tab. 1). No relationship between body weight status and risk of orthorexia was observed in either group (WULS $\mathrm{p}=0.359$; WUR $\mathrm{p}=0.255$ ). The dominant place of residence among WULS students were cities with more than 500,000 inhabitants, while at the WUR they were cities with 10,000 - 50,000 inhabitants.

Most of the respondents assessed their financial situation as average and declared education in engineering or bachelor studies. Nearly $32 \%$ of the study group from WULS and $28 \%$ from WUR studied on a nutritional and dietetics programme. No significance was found between the field of study and orthorexia nervosa $(\mathrm{p}>0.05)$. The study groups were characterized by moderate physical activity (approx. $49 \%$ of students). A trend between the level of physical activity and orthorexia nervosa was observed in WULS students $(p=0.052)$, whereas in WUR students, a significant effect occurred $(\mathrm{p}=0.008)$.

Dietary supplements were taken by 41 WULS students and 38 students from WUR. There was no relationship between taking supplements and orthorexia among WULS students ( $>0.05)$ compared to students from WUR $(p=0.002)$. Less than $20 \%$ of WULS students and more than $5 \%$ fewer students from WUR declared smoking tobacco products. Most respondents smoked daily or less than 1-3 times a week. However, alcohol consumption was more frequent (72\% of WULS people; $78 \%$ of WUR), most often 1-3 times a week $(n=82 ; n=80$, respectively). Smoking and alcohol consumption were not associated with orthorexia. The study group declared assessment of their diet mainly at a level of at least a good 54\% WULS, 67\% WUR). Only about $12 \%$ of WULS students and 7\% of WUR students declared their diet as bad or very bad. Compared to their peers, they rated their health as comparable or better ( $55 \%$ or $25 \%$ WULS; $50 \%$ or $39 \%$ WUR, respectively).

In the study groups, the risk of orthorexia was observed in less than $1 / 3$ of WULS students (average points $36.6 \pm 3.7$ ) and in more than $1 / 4$ of WUR students (average points $37.2 \pm 4.6$ ). There were no differences in the prevalence of orthorexia between universities (Tab. 2).

Only $25 \%$ of the examined group from WULS and $31 \%$ from WUR declared adherence to the diet during the study. Twenty-four students from WULS implemented a diet of their choice and at the suggestion of a physician (6 respondents). In the case of WUR students, this was 35 people (independent decision) and 3 respondents (physician`s recommendation). No significance relationship was observed between orthorexia

Table 2. Risk of orthorexia nervosa among WULS and WUR students at 35 points cut off $(n=240)$

\begin{tabular}{lccc}
\hline & Total WULS $(\mathrm{n}=118)(\%)$ & Total WUR $(\mathrm{n}=122)(\%)$ & P-value \\
\hline Orthorexia & $35(29.7)$ & $32(26.2)$ & \multirow{2}{*}{0.818} \\
\cline { 1 - 3 } No risk & $83(70.3)$ & $90(73.8)$ & \\
\hline
\end{tabular}


Table 3. Products recognized as 'superfoods' by respondents $(n=240)$ from WULS and WUR, including the orthorexia risk criterion

\begin{tabular}{|c|c|c|c|c|c|c|c|c|c|}
\hline & \multirow{2}{*}{$\begin{array}{l}\text { Total WULS } \\
(n=118)(\%)\end{array}$} & \multicolumn{2}{|c|}{ WULS } & \multirow{2}{*}{$\begin{array}{l}\text { P-value WULS } \\
\text { orthorexia vs. } \\
\text { superfood }\end{array}$} & \multirow{2}{*}{$\begin{array}{c}\text { Total } \\
\text { WUR }(n=122) \\
(\%)\end{array}$} & \multicolumn{2}{|c|}{ WUR } & \multirow{2}{*}{$\begin{array}{c}\text { P-value WUR } \\
\text { orthorexia vs. } \\
\text { superfood }\end{array}$} & \multirow{2}{*}{$\begin{array}{c}\text { P-value } \\
\text { WULS vs. WUR }\end{array}$} \\
\hline & & Orthorexia (n) & $\begin{array}{c}\text { Lack of } \\
\text { orthorexia (n) }\end{array}$ & & & Orthorexia (n) & $\begin{array}{c}\text { Lack of } \\
\text { orthorexia (n) }\end{array}$ & & \\
\hline Acai berry & $34(28.8)$ & 12 & 22 & 0.394 & $37(30.3)$ & 10 & 27 & 0.895 & 0.467 \\
\hline Aloe & $72(61)$ & 25 & 47 & 0.132 & 45 (36.9) & 9 & 36 & 0.232 & 0.859 \\
\hline Amaranth & $36(30.5)$ & 16 & 20 & 0.019 & $12(9.8)$ & 5 & 7 & 0.201 & 0.662 \\
\hline Chia seeds & 70 (59.3) & 25 & 45 & 0.082 & $50(41)$ & 14 & 36 & 0.711 & 0.243 \\
\hline Ginger & $90(76.3)$ & 26 & 64 & 0.742 & $86(70.5)$ & 24 & 62 & 0.515 & 0.885 \\
\hline Ginseng & $78(66.1)$ & 22 & 56 & 0.629 & $28(23)$ & 7 & 21 & 0.866 & 0.944 \\
\hline Goji berry & $59(50)$ & 20 & 39 & 0.314 & $43(35.3)$ & 13 & 30 & 0.458 & 0.339 \\
\hline Turmeric & $59(50)$ & 21 & 38 & 0.158 & $36(29.5)$ & 12 & 24 & 0.249 & 0.158 \\
\hline
\end{tabular}

Table 4. Consumption of 'superfoods' products among students $(n=240)$ from WULS and WUR, including the orthorexia risk criterion

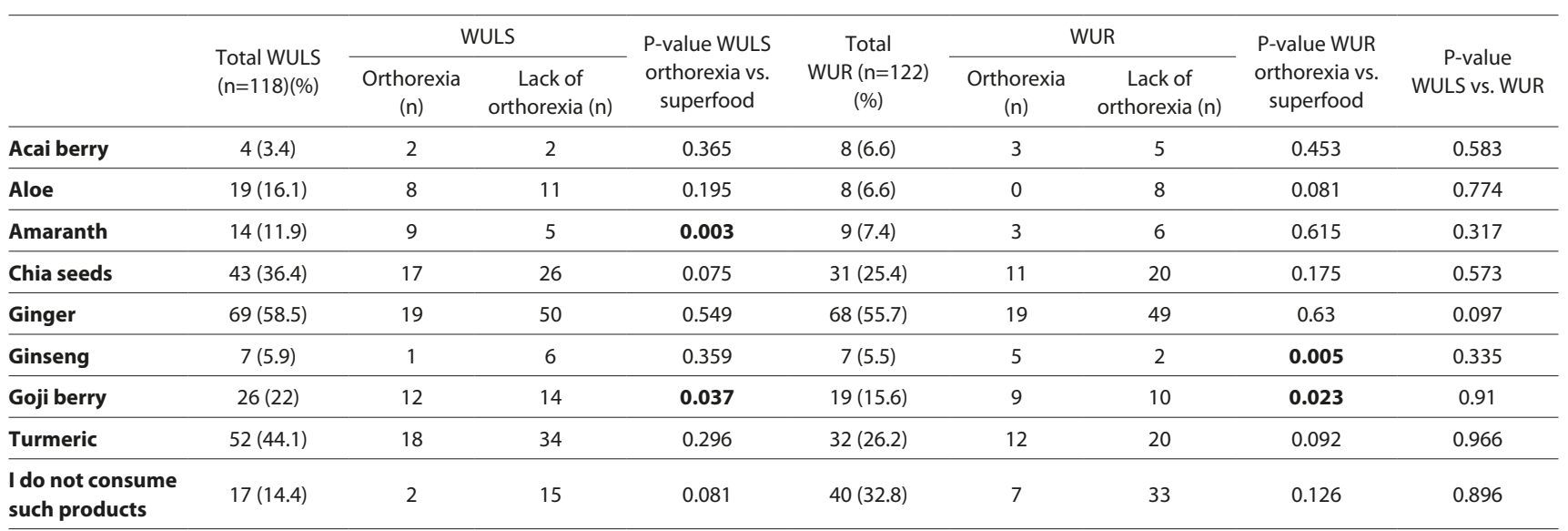

and adherence to the diet (WULS $\mathrm{p}=0.152$; WUR $\mathrm{p}=0.193$ ). Among the implemented diets the most common was a vegetarian / vegan diet (WUR students -28 , WULS students - 12). Students following these diets from both universities did not show a significant tendency to orthorexia ( $p>0.05$ ). Among the most often declared products with significant prohealth potential by WULS students were: ginger, ginseng and aloe, whereas among WUR students: ginger, chia seeds and aloe. However, only 17 people from WUR did not recognize 'superfood' products as products with special health properties. Statistical significance between the tendency to orthorexia and knowledge of this type of product occurred only in the case of amaranth among students of WULS. WULS and WUR students did not differ statistically in their knowledge of 'superfood' products (Tab. 3). Respondents mainly obtained knowledge about 'superfood' products from the Internet [WULS = 108, (85\%); WUR=96 (75.6\%)], as well as from scientific journals (WUR $n=47,37 \%$ ), popular science papers (WULS $n=33,26 \%$ ) and from acquaintances [WULS = 38 (29.9\%); WUR= 41 (32.3\%)]. Among WULS and WUR students, ginger and turmeric were the most commonly consumed. Relationship between orthorexia nervosa and consumption of 'superfood' products was observed among WULS students for goji berries and amaranth. Among WUR students, such a relationship was observed for ginseng and goji berries. However, WULS and WUR students did not differ in the consumption of 'superfoods' (Tab. 4).

WULS students most often consumed 'superfood' several times a month or less; similar observations were noted in WUR students. Only 7 students from WULS and 13 students from WUR declared consumption at least once a day (Tab. 5). Most respondents from both universities did not notice any change in their health status after introducing 'superfood' into their diet (WULS $n=58$; WUR $n=61$ ), however some of the examined individuals reported some improvement $(\mathrm{WULS} n=41$; WUR $\mathrm{n}=21$ ). In 2 students at WULS, the condition worsened. WULS and WUR students most often purchased 'superfood' products in a supermarket $(n=64 ; n=67$, respectively), as well as in a health food store $(n=13 ; n=8)$.

Table 5. Frequency of consuming 'superfood' products by respondents from WULS and WUR $(n=240)$

\begin{tabular}{lcc}
\hline & WULS $(\mathrm{n}=118)(\%)$ & WUR $(\mathrm{n}=122)(\%)$ \\
\hline A few times per day & $1(0.9)$ & $1(0.8)$ \\
\hline Once a day & $6(5.1)$ & $12(9.8)$ \\
\hline 4-6 times per week & $11(9.3)$ & $6(4.9)$ \\
\hline 2-3 times per week & $24(20.3)$ & $19(15.6)$ \\
\hline 1-3 times per month & $38(32.2)$ & $21(17.2)$ \\
\hline Less than 1-3 times per month & $21(17.8)$ & $23(18.9)$ \\
\hline I do not consume such products & $17(14.4)$ & $40(32.8)$ \\
\hline
\end{tabular}

\section{DISCUSSION}

More women were involved in this study, which has also been observed in other studies $[2,10,11,12]$. The lack of 
relationship between orthorexia prevalence and gender was also noted in a larger number of students studied in the Polish population $(\mathrm{n}=327)$ [11], $(\mathrm{n}=1120)$ [2]. Similar results were obtained during the observation of university students in Turkey $(\mathrm{p}=0.000)$ [13]. Current results regarding the lack of relationship between the prevalence of orthorexia in women and men confirm other similar studies $(\mathrm{p}=0.719$, Poland) [11], $(\mathrm{p}=0.88, \mathrm{UK})$ [14]. The average age in the current study group was similar to others conducted among students in Poland [11], Spain [12] and Turkey [13]. The lack of relationship between age and risk of orthorexia is confirmed by similar studies in students $(p=0.151)$ [14]. Also, in the context of the body weight status in relation to the orthorexia nervosa tendency, no significance was demonstrated $[13,15,16]$, including the Polish study [2]. In the study group of Polish students, variables such as place of residence or level of study were, in percentage, similar to those in the Polish population in the study by Plichta et al. and differ from the current study group from WUR [2]. There was no relationships in taking supplements and the risk of orthorexia in the study among a group of Hungarian students $(\mathrm{p}=0.19)$, which is consistent with students from WULS, but different from WUR students [17]. Physical exercises were more frequently performed than the $38.5 \%$ of people in the study by Brytek-Matera [11]. Clifford and Blyth [18] observed lack of relationship between orthorexia nervosa in athletics students and non-athletic students. The authors conclude that a greater risk of orthorexia may be associated only with the performance of large physical efforts [18]. Students from Hungary who declared greater physical activity had lower results in the ORTO-11-Hu questionnaire, i.e. demonstrating a greater risk of having this disorder [17]. The presented data on smoking and alcohol consumption did not differ significantly from the results of students from Poland [11]. Referring to the study on a student group in Hungary the current study results regarding the lack of relevance in the case of smoking and orthorexia are comparable, while differing in alcohol consumption $(\mathrm{p}<0.05)$ [17]. In the Barnett et al. study [19], a similar percentage of respondents followed a diet (a quarter of respondents), and slightly more than the students of WUR [19].

In the current study, mainly vegetarian and vegan diets were followed. The results of the literature review by BrytekMatera showed that vegetarian diets were associated with a higher risk orthorexia nervosa (11 out of 14 tests), which has been not confirmed in the presented study [20]. Being in the group of young people, such as students whose personality is developing, may be conducive to the trend of orthorexia disorder [4]. This is particularly indicated by the results of students from Poland (65\%, ORTO-15, z-score 24) [11], from Hungary (74.2\%, ORTO-15, z-score 40) [17], compared to another study on a student population from Polish universities (28.3\%, ORTO-15, z-score 35) [2].

Among the popular sources mentioned by students searching for knowledge about nutrition, were social media, blogs, and other websites (60.3\%) as the most commonly used. In addition, professional magazines and magazines were often used, as well as acquaintances [10]. Barnett et al. [19] have shown that adults characterized by preference to alternative food networks, such as health food stores, regional and ecological stores, were often prone to orthorexia. This is not very consistent with the current results, which may be due to the small percentage of people exposed to this eating disorder.
Most often, students mentioned ginger as healing product [21]. The health-promoting effect of ginger on the human body depends mainly on the presence of phytonutrients, such as monoterpenes and sesquiterpenes. It works as an antidiabetic, hypolipidemic, antimicrobial, antioxidant, and anticoagulation agent [22]. It helps in relieving menstrual pain and has an anti-migraine effect, as well as inhibiting the development of cancer cells or causes their apoptosis in prostate cancer [23]. Among other products with a special health-promoting effect are goji berries. They can also be an effective product in the treatment of diabetes, cardiovascular diseases and cancer. They improve insulin sensitivity and lipid parameters $[24,25]$. Regular consumption of chia seeds lowers total and VLDL cholesterol levels, while increasing HDL. Significantly reduces systolic blood pressure in patients with hypertension, inhibits postprandial hyperglycaemia and reduces the level of inflammatory marker - C-reactive protein [26]. The literature also points to the wide action of amaranth, rich, among others, in vitamins and minerals, as well as tocopherols, squalene and phytosterols. It has a beneficial effect on the cardiovascular system and lipid profile, lowers blood glucose levels, has antimicrobial and antioxidant properties [27].

Depending on the Aloe species, a different range of pharmacological effects can be seen. Studies in humans show that the bioactive activity of the Aloe plant includes anti-inflammatory, anti-diabetic and anti-hyperlipidemic effects. It is used to treat dental and oral diseases, as well as for AIDS. It can also help wound healing and cell proliferation [28]. Turmeric, mainly its substance - curcumin, has a wide therapeutic potential. For example, it has anti-rheumatic and anti-arthritic properties. It reduces inflammation by interacting with many inflammatory processes, it can also complement the therapy of neurological and cancer diseases or reduce the effects of treatment [29]. Similarly, ginseng, which also shows a reduction in blood glucose, has anticancer, antioxidant, as well as anti-inflammatory effects. In addition, it modulates appetite, reduces fat accumulation in white adipose tissue. It can support Alzheimer's disease and protect the liver $[30,31,32]$. From the meet-analysis of Bach et al., it appears that although ginseng can effectively reduce fatigue, it does not increase physical performance [33]. Acai berries contain ingredients such as anthocyanins, flavonoids, lignans, and polyphenolic acids. Acai berries additionally have beneficial effects on carbohydrate and lipid metabolism, antioxidant activity, and cause a chemopreventive effect [6].

\section{CONLUSIONS}

The relationship between orthoretic behaviour and knowledge and consumption of 'superfoods' products has been demonstrated only for 3 products. However, the results could have been affected bythea small percentage of respondents with a confirmed risk of orthorexia.

Despite the differences in physical activity and the type of consumed products between respondents from both countries that may result from cultural differences or product availability, no differences in the prevalence of orthorexia were observed.

Further research is recommended on a larger number of people to determine more accurately whether orthorexia nervosa can be associated with an attitude and nutritional behaviors towards 'superfood' products. 
Due to the relatively poor state of knowledge regarding the connection between orthorexia and attitudes to 'superfood' products, it is worthwhile for health professionals and public health educators to pay attention not only to orthoretic behaviour, but also attitudes towards 'superfoods' among groups at increased risk of eating disorders. Due to the lack of scientific confirmation of the benefits of consuming 'superfoods', a balanced diet based on a variety of food products should be promoted to obtain and maintain a healthy state of nutrition and health.

\section{Acknowledgments}

The authors thank Jacek Nowik for help in collecting data. Also thank respondents for their willingness to participate in the study.

\section{Funding}

The study was performed without financial support.

\section{Conflict of interest}

The authors declare no conflict of interest.

\section{REFERENCES}

1.Łucka I, Janikowska-Hołoweńko D, Domarecki P, Plenikowska-Ślusarz T, Domarecka M. Ortoreksja - oddzielna jednostka chorobowa, spektrum zaburzeń odżywiania czy wariant zaburzeń obsesyjnokompulsywnych? Psychiatr Pol. 2019; 53(2): 371-382. https://doi. org/10.12740/PP/OnlineFirst/85729

2.Plichta M, Jeżewska-Zychowicz M, Gębski J. Orthorexic tendency in Polish students: exploring association with dietary patterns, body satisfaction and weight. Nutrients. 2019; 11(1): 100. https://doi. org/10.3390/nu11010100

3. McComb SE, Mills JS. Orthorexia nervosa: A review of psychosocial risk factors. Appetite. 2019; 140: 50-75. https://doi.org/10.1016/j. appet.2019.05.005

4. Kałędkiewicz E, Doboszyńska A. Ortoreksja na tle innych zaburzeń odżywiania. Forum Med Rodz. 2013; 7(6): 307-315.

5. Ambwani S, Shippe M, Gao Z, Austin SB. Is cleaneating a healthy or harmful dietary strategy? Perceptions of clean eating and associations with disordered eating among young adults. J Eat Disord. 2019; 7: 17. https://doi.org/10.1186/s40337-019-0246-2

6. Wojciechowska M, Grzegorczyk-Karolak I. Owoce açaí - potencjał terapeutyczny bazujący na profilu fitochemicznym surowca i współczesnych badaniach farmakologicznych. Farm Pol. 2019; 75(3): 134-147. https://doi.org/10.32383/farmpol/116289

7. Ekiert K, Dochniak M. Superfoods - idealne uzupełnienie diety czy zbędny dodatek? Piel Zdr Publ. 2015; 5(4): 401-408. https://doi.org/ $10.17219 / \mathrm{pzp} / 60915$

8. Stochel M, Janas-Kozik M, Zejda JE, Hyrnik J, Jelonek I, Siwiec A. Walidacja kwestionariusza ORTO-15 w grupie młodziezy miejskiej w wieku 15-21 lat. Psychiatr Pol. 2015; 49(1): 119-134. https://doi. org/10.12740/PP/25962

9. Database on Body Mass Index, http:/www.euro.who.int/en/healthtopics/disease-prevention/nutrition/a-healthy-lifestyle/body-massindex-bmi (dostęp 09.04.2020).

10. Olejniczak D, Bugajec D, Panczyk M, Brytek-Matera A, Religioni U, Czerw A, et al. Analysis concerning nutritional behaviors in the context of the risk of orthorexia. Neuropsychiatr Dis Treat. 2017; 13: 543-550. https://doi.org/10.2147/NDT.S129660

11. Brytek-Matera A, Donini LM, Krupa M, Poggiogalle E, Hay P. Orthorexia nervosa and self-attitudinal aspects of body image in female and male university students. J Eat Disord. 2015; 3: 2. https:/doi.org/10.1186/ s40337-015-0038-2

12. Parra-Fernandez ML, Rodríguez-Cano T, Onieva-Zafra MD, PerezHaro MJ, Casero-Alonso V, Muñoz Camargo JC, et al. Adaptation and validation of the Spanish version of the ORTO-15 questionnaire for the diagnosis of orthorexia nervosa. PLoS One. 2018; 13(1): e0190722. https://doi.org/10.1371/journal.pone.0190722

13. Sanlier N, Yassibas E, Bilici S, Sahin G, Celik B. Does the rise in eating disorders lead to increasing risk of orthorexia nervosa? Correlations with gender, education, and body mass index. Ecol Food Nutr. 2016; 55(3): 266-278. https://doi.org/10.1080/03670244.2016.1150276

14. Albery IP, Michalska M, Moss AC, Spada M. Selective attentional bias to food-related stimuli in healthy individuals with characteristics towards orthorexia nervosa. Eat Weight Disord. 2019. https://doi.org/10.1007/ s40519-019-00755-z

15. Poyraz CA, Tüfekçioğlu EY, Özdemir A, Baş A, Kani AS, Erginöz E, et al. Relationship between orthorexia and obsessive-compulsive symptoms in patients with generalised anxiety disorder, panic disorder and obsessive-compulsive disorder. Yeni Symp. 2015; 53(4): 22-26. https://doi.org/10.5455/NYS.20160324065040

16. Cinosi E, Matarazzo I, Marini S, Acciavatti T, Lupi M, Corbo M, et al. Prevalence of orthorexia nervosa in a population of young Italian adults. Eur Psychiatry. 2015; 30: 1330. https://doi.org/10.1016/S09249338(15)31038-5

17. Varga M, Thege BK, Dukay-Szabó S, Túry F, van Furth EF. When eating healthy is not healthy: Orthorexia nervosa and its measurement with the ORTO-15 in Hungary. BMC Psychiatry. 2014; 14: 59. https://doi. org/10.1186/1471-244X-14-59

18. Clifford T, Blyth C. A pilot study comparing the prevalence of orthorexia nervosa in regular students and those in University sports teams. Eat Weight Disord. 2019; 24(3): 473-480. https://doi.org/10.1007/s40519018-0584-0

19. Barnett MJ, Dripps WR, Blomquist KK. Organivore or organorexic? Examining the relationship between alternative food network engagement, disordered eating, and special diets. Appetite 2016; 105: 713-720. https://doi.org/10.1016/j.appet.2016.07.008

20. Brytek-Matera A. Vegetarian diet and orthorexia nervosa: a review of the literature. Eat Weight Disord. 2019. https://doi.org/10.1007/s40519019-00816-3

21. Żwirska J, Żyła K, Błaszczyk E, Jagielski P, Schlegel-Zawadzka M. Źródła wiedzy i zastosowanie przypraw ziołowych przez osoby dorosłe zamieszkujące okręg małopolski i śląski. Bromatol Chem Toksykol. 2015; 48(3): 594-598.

22. Kulczyński B, Gramza-Michałowska A. Znaczenie żywieniowe imbiru. Bromatol Chem Toksykol. 2016; 49(1): 57-63.

23. Glibowski P, Długołęcka A, Grdeń A, Toczek K. Właściwości prozdrowotne imbiru. Bromatol Chem Toksykol. 2017; 50(2): 115-121.

24. Kulczyński B, Gramza-Michałowska A. Kompleks polisacharydowy jagód Goji (Lycium barbarum) jako element fitoterapii - przegląd literatury. Post Fitoter. 2014; 4: 247-251.

25. Kulczyński B, Gramza-Michałowska A. Goji Berry (Lycium barbarum): Composition and health effects - a review. Pol J Food Nutr Sci. 2016; 66(2): 67-75. https://doi.org/10.1515/pjfns-2015-0040

26. Karbowska J, Kochan Z. Szałwia hiszpańska (chia) jako bogate źródło kwasów wielonienasyconych n-3 o działaniu przeciwmiażdżycowym i kardioprotekcyjnym. Postępy Hig Med Dośw. 2018; 72: 307-317. https:// doi.org/10.5604/01.3001.0011.7987

27. Kulczyński B, Gramza-Michałowska A, Grdeń M. Amarantus - wartość odżywcza i właściwości prozdrowotne. Bromatol Chem Toksykol. 2017; 50(1): $1-7$.

28. Salehi B, Albayrak S, Antolak H, Kręgiel D, Pawlikowska E, SharifiRad M, et al. Aloe Genus Plants: From farm to food applications and phytopharmacotherapy. Int J Mol Sci. 2018; 19(9): 2843. https://doi. org/10.3390/ijms19092843

29. Pulido-Moran M, Moreno-Fernandez J, Ramirez-Tortosa C, RamirezTortosa M. Curcumin and health. Molecules. 2016; 21(3): 264. https:// doi.org/10.3390/molecules21030264

30. Metwaly AM, Lianlian Z, Luqi H, Deqiang D. Black ginseng and its saponins: Preparation, phytochemistry and pharmacological effects. Molecules 2019; 24(10): 1856. https://doi.org/10.3390/molecules 24101856

31.Li Z, Ji GE. Ginseng and obesity. J Ginseng Res. 2018; 42(1): 1-8. https:// doi.org/ 10.1016/j.jgr.2016.12.005

32. Kim HJ, Jung SW, Kim SY, Cho IH, Kim HC, Rhim H, et al. Panax ginseng as an adjuvant treatment for Alzheimer's disease. J Ginseng Res. 2018; 42(4): 401-411. https://doi.org/10.1016/j.jgr.2017.12.008

33. Bach HV, Kim J, Myung SK, Cho YA. Efficacy of ginseng supplements on fatigue and physical performance: A meta-analysis. J Korean Med Sci. 2016; 31(12): 1879-1886. https://doi.org/10.3346/jkms.2016.31.12.1879 